\title{
Chapter 10. Seating the Place: Tropes of body, movement and space for the people of Lelet Plateau, New Ireland (Papua New Guinea) ${ }^{1}$
}

\section{Richard Eves}

In what ways do people attach meaning to and organize space and place? (Tuan 1977:5).

In this paper I explore the relationship between people and place. My aim is to show how space is transformed into lived space or place. I explore the way that people conceive of themselves through the space that they imaginatively create around them. In particular, I show how this relationship is constituted through the body and through tropes of the body.

My discussion is based on ethnographic research among the Austronesian-speaking people of the Lelet Plateau in the New Ireland province of Papua New Guinea. The Lelet are the only remaining residents of the mountainous backbone of New Ireland, having resisted colonial pressure to relocate to the coastal fringe, as other inland populations have done. The population of about 500 people live in widely dispersed hamlets centred around four main villages which form the nucleus of social and political life. Like others in the Mandak language area, the Lelet are divided socially into two exogamous matrilineal moieties - Lamalom or Laragam. These moieties are further divided into matriclans and matrilineages. These people are swidden agriculturalists whose main crops are taro and sweet potato, with taro being - culturally and symbolically - the most valued.

Images of the body pervade Lelet conceptualizations of the way the world is constructed and inhabited. The use of corporeal tropes is an important part of the process by which these people develop attachment to their place (lemenemen). ${ }^{2}$ They construct a cosmology of space and place around the contrasting images of bodily comportment, especially those of an immobile body and a mobile body. I am not posing an immutable binarism here but pointing to the importance of the tropic constructions of the body and the flow of figurative possibilities that are imaginatively fashioned in this world view. ${ }^{3}$

These processes, using the body and tropes drawn from it, are examples of what Jackson (1989:138) has referred to as "thinking through the body". The tropic use of the body in constituting space and place is only one part of a wider 
process of the body's interaction with, and constitution of, the world. The body in its movement through space is integral to the process by which the world is known, valued and inhabited. In short, body movement for these people is integral to the transformation of space into lived place. An aim of this paper is to illustrate the play of tropes, or that process of "thinking through the body", as the Lelet negotiate the tension between the culturally constructed requirement of seating - or remaining in place, with its connotations of social harmony and the requirement to engage in movement, as a precursor of social interaction.

In the first part of this paper, I discuss some recent anthropological explorations of space and place. I then develop an analysis based on the work of Merleau-Ponty (1962), whose theory of lived spatiality locates the body in a centrally important position in the constitution of space as place. In the second part, I examine the symbolic construction of socially adopted space - in particular the manner in which powerful spirit beings define place for people. A primary association of people and their attachment and location in place is through these tutelary spirits, larada (masalai), who demarcate the landscape along matriclan lines (see also Jessep 1980). I use the example of the relationship of people with their larada to illustrate the contradiction between the desirability of being in place and the social imperative of movement within and away from place. In the third part, I discuss the notion of seating and describe contexts in which this body trope has significant meanings. Finally I examine the notion of mobility and its subversion of the trope of the place as (harmoniously) seated when people engage with others in constituting their social world.

\section{Beyond Cartesian Dichotomies: Conceptualizing Space and Body}

A number of commentators have drawn attention to the constitution of place and the importance of this for anthropological understanding (see also Feld 1982; Munn 1986; Pandolfo 1989; Pandya 1990; Stoller 1980 and Weiner 1992). Appadurai (1988:16), for example, has written that the "problems of place and voice are vital to anthropological practice and so is the relationship between them". Rodman argues that the question of voice has received considerable attention but that of place has not. She argues that the concept of place requires a rethinking and that "It is time to recognize that places, like voices, are local and multiple" (1992:643). Rodman suggests that, at best, place has been "seen purely as locale and the 'problem' is defined as if place were entirely an anthropological creation" (p.644). Following Entrikin (1991), Rodman says that the analysis of place requires examination of what she terms the "betweenness of place' in anthropological contexts, as both subject and object" (p.644).

In a similar vein, Basso (1988:101) has drawn attention to Western Apache representation of their landscape in ways that "are compatible with shared understandings of how, in the fullest sense, they know themselves to occupy 
it" $^{\prime \prime}$. Following Heidegger (1962), Basso suggests that, just as people dwell in their landscape, that landscape is said to dwell in them. This is because the conceptions the Apache use to fashion their inhabited landscape are the same as those used to constitute Apache persons (Basso 1988:122). In the reciprocal process of inhabiting the landscape and being inhabited by it, the Western Apache and landscape become "virtually one" (p.122).

Thus Basso, like Rodman, sees place not simply as an object external to people but as constitutive of their being. This view is succinctly explained by Dreyfus: "The relation between me and what I inhabit cannot be understood on the model of the relation between subject and object" (1991:45). ${ }^{4}$ While the arguments of Rodman and Basso are admirable, neither explores the full extent to which the way that people inhabit their world is predicated on a notion of the body and its movement - either the body itself or tropes drawn from the body and its comportments. I suggest that Merleau-Ponty (1962) offers a useful perspective of the "problem" of place in his critique of Cartesianism, where he places the body in a pivotal role as mediator between people and world (see also Jackson 1989:122; I.M. Young 1990a, 1990b). Previously in the philosophical tradition and in Euclidean geometry, space has been conceptualized in a limited sense as uniform, physical or geometrical, the container in which objects of experience are located (Langer 1989:80; see also Dreyfus 1991:139). In the measured space of Cartesianism, positions are external to one another and interchangeable (I.M. Young 1990a:151; see also Madison 1990).

In his critique of traditional conceptions of space, Merleau-Ponty (1962) argues that there is a distinction between lived, or phenomenal, space and the Cartesian, or objective, space of geometry and science. Similar Cartesian conceptions are to be found in theories of the body, where the division between subject and object reduces the body to another part of the quantifiable and measurable world of physical science (Jackson 1989:119). Since the seventeenth century the body has

been primarily identified with its scientific description, i.e., regarded as a material object whose anatomical and functional properties can be characterized according to general scientific law (Leder 1990:5).

Accordingly, the body is seen as essentially no different from any other physical object.

In opposition to this view, Merleau-Ponty sees the body not simply as an object in the world but as the means through which the world comes into being. In his concepts of the lived body and lived spatiality, Merleau-Ponty transcends the dichotomizations of previous conceptualizations of space, by placing the body to the forefront. He rejects the traditional Cartesian conceptions of space and body, focusing instead on the "dynamic pre-objective, pre-logical interaction 
of body-subject and world" (Langer 1989:88). Especially important is the figure-background or point-horizon structure against which any body in space is located and which changes according to movements of that body. Thus Merleau-Ponty writes:

As far as spatiality is concerned ... one's own body is the third term, always tacitly understood, in the figure-background structure, and every figure stands out against the double horizon of external and bodily space. One must therefore reject as an abstraction any analysis of bodily space which takes account only of figures and points, since these can neither be conceived nor be without horizons (1962:101).

According to Merleau-Ponty's phenomenology of lived space, spatiality cannot be conceived without horizons; neither can it be conceived without the movement of the body against those horizons. The figure-background structure which the body inhabits

becomes the background against which movement can stand out; consequently, movement presupposes inherence in the world which is established and maintained by the habitual body (Langer 1989:87).

Merleau-Ponty argues that by considering the body in movement, a better understanding can be gained as to how it inhabits space:

because movement is not limited to submitting passively to space and time, it actively assumes them, it takes them up in their basic significance which is obscured in the commonplaceness of established situations (1962:102, and see also Straus 1966:45).

For him, movement as a basis of intentionality or consciousness (or his technical term, "motility") becomes not solely "a matter of 'I think that' but of 'I can' " (1962:137).

But, while Merleau-Ponty's theory is valuable in understanding how the body inhabits space, particularly how bodily movement is constitutive of space, any full conceptualization of space must be coupled with an analysis of, and be grounded in, a concept of space as social space. The movement of the body, which Merleau-Ponty sees as important to the constitution of space, does not exist outside of people's symbolic construction of socially inhabited space and also of the body. Thus, for the people of the Lelet Plateau, the movement of the body is not absolutely free or unhindered, as Merleau-Ponty presupposes, but is regulated and restricted by the cultural conceptions of social space. To gain an accurate picture of the way space is given meaning and transformed into place requires an understanding of the means through which social space is constituted by symbolic processes. 


\section{Larada: Delineating and Demarcating Space}

Larada (masalai) are territorial beings located on a clan's land but are by no means permanently "seated" there, having the capacity to leave one abode for another, or one place for another. ${ }^{5}$ This is one of the primary means through which space becomes demarcated and thus recognized as place. The travels of larada and the sites at which they settle are also part of the process by which the land is named; the Lelet Plateau is dotted by numerous abodes named in this way. Knowledge of the origins of these names, and of the means by which the larada came to be there, is significant in the justification of claims on land. Larada, I was told, "get up and sit down in other places". This ability to move, and thus to migrate, means that a clan's land can be scattered over a large geographical area. These dispersed clan lands are an indication of the past migrations of the larada and, reciprocally, of the clans that inhabit that land. Like the Dreaming stories of the Australian Aborigines, a mythic topography of place is crafted as these powerful beings traverse the landscape, structuring undomesticated space into place (see Myers 1986:48).

The movement of larada from their abodes — lubungtada (ples masalai) can be temporary or permanent. Their temporary movement, referred to as larada lalan, is common at night. Larada that do not roam around are referred to as larada kitkis, meaning "the larada are firmly seated". The temporary travel of larada is not random or arbitrary but is along well-known paths between abodes. They are said to move from the dominant or central abode - the laxatlitada ("eye" of the larada) — to other sites dispersed around a clan's lands. These other lubungtada may be situated nearby or several kilometres away, depending on how many separate parcels of land belong to a clan. For example, Simut, a snake larada of the clan Katanuat, resides near a large tree located close to the hamlet Lenuat but sometimes changes places with another snake larada living at a tree-lined ridge a few hundred metres away. Simut also travels to other larada abodes, such as Latbeve, and formerly visited a water-hole abode called Merakeke, now dry and no longer an abode.

Narrative accounts of the permanent movement of larada explain the way clans come to migrate, colonize and inhabit new lands. In these stories, larada have travelled to other places and, in that movement, have claimed new areas of land for their clan. At these times, the larada in their embodied forms often move along valleys of unowned land, making paths which open up vacant space for colonization. Land that has already been delineated by other larada, and thus claimed, cannot be reclaimed. If a migrating larada attempts to traverse land already claimed by another larada, the latter will be angered.

The following origin narrative illustrates this claiming of land through larada movement. The clan of Luben had its beginning in the sea at Kinaba on the west coast of New Ireland, in an oyster (laxalas), the shell of which is used by women 
to peel taro. In this originary time, some men were on a reef, fishing with a net (uben). Nearby there was a larada abode - a lubungtada - a hole in the ocean called Kanemara. This larada was avoided by people in canoes, for if a person's shadow were cast into the hole, that person would die. The oyster larada would not leave its abode during the day, but only at night. One night when the oyster larada was moving about on the reef, it was caught by the fishermen in their uben. When they had caught enough fish, the fishermen went ashore to divide their haul and then to cook some of it. They decided to cook and eat the captured oyster larada. It was placed on the fire to cook and thus to open, but to no avail. They tried to open it with a knife, but this also failed. One man then tried to smash the oyster open with a rock, but this did not succeed either, the oyster remaining intact. Finally admitting defeat, the men threw the oyster away. During the night when the fishermen were all asleep the larada communicated through a dream with the man who had tried to smash the oyster open. The oyster told the man that he would from now on bear the name of uben and the larada would be his guardian.

The clan legend of Luben continues: the discarded oyster, together with the fishermen's net which also became a larada, journeyed from this site to a water-hole at a place named Sarum. This water-hole then became a larada of the clan Luben. The oyster larada, however, did not remain "seated" here for very long because a person in an avoidance relationship with it visited the pool. This lack of respect caused the oyster larada to flee once again. From this coastal area, it moved into the mountains of the Lelet, journeying via the hamlet Tumalom at Kaluan, where it found that all of the land was already occupied by other larada, and thus other clans. It then moved to the other side of the plateau where it found an unoccupied area of land. Here the oyster larada and its companion went to a place where the oyster made a hole for the net to reside in. This larada abode was named Lubentada after the primary larada residing there - the Luben. Afterwards, the oyster larada journeyed to another place and made a hole there, naming this place after itself - Lurugalas-silok. It then moved and made a further hole, also naming it after itself - Lurugalas-lik. Finally, when the oyster larada made its abode, the net larada Luben moved to demarcate the boundaries of the Luben clan land, in a way similar to that used in enclosing and trapping fish. As Luben journeyed along valleys and over mountains, mapping the space of its land, it occasionally came to the boundaries of other clan lands, so that it was forced to change its route. For example, in the south its path was restricted by the land of the clan Kantaon, in the north-east by the land of the Bungaring, and in the west by the land of the Solong.

The Luben clan leader who told me this legend of the origins of his clan and its larada admitted that he had never seen the oyster larada, but he authenticated his story by pointing out that coastal vegetation grows at the places where the larada now resides. Further authenticity is furnished by the existence of an 
omen that indicates impending death of a member of the Luben clan. Should a Luben member be about to die, the oyster larada makes an exploding sound.

The narratives of the movements of larada are the means through which the landscape is imaginatively fashioned, giving people identification and attachment to place. The wandering movements are part of the process by which the space is named and transformed into meaningful lived or socialized space or place when the larada - and following them, people - finally take up residence. These movements become the inscription or signature which verifies and authenticates ownership of that landscape. The narratives serve not only as the means by which emotional and aesthetic roots are attached to place, but they are also important in giving people genealogical connection to that land, and thus rights of ownership and control. Once the larada have ceased their travels, their human clan members can legitimately occupy the newly colonized land becoming "seated" in place. This "seating" for larada, as well as for their clan members, while giving the illusion of permanence, is nonetheless subject to contingencies that require journeying to be resumed.

\section{Larada Spirits: The Attachment of People to Their Place}

As Tuan notes "Space is transformed into place as it acquires definition and meaning" (1977:136). Larada are pre-eminent in giving this definition and meaning to place. ${ }^{6}$ These larada are powerful tutelary spirit beings rooting or locating particular clans in bounded locales and giving them an abiding attachment to that land and place. These spirit beings, which like humans have the ability to move from their place, enact the dialectical tension between immobility (being seated in place) and mobility (movement away from place).

Larada are powerful, knowledgeable and, in some circumstances, vengeful clan-based spirits who can take on multiple bodily configurations. They have a transformative potential and consciousness that allows them to occupy different bodies, spaces and ontological states for any reason. Sometimes these forms are visible, such as the phenomenal form of a snake, or invisible, and experienced only through revelatory dreams. They can manifest themselves in many forms such as those of possum, dog, pig, eel, oyster, shark or octopus. They can also embody or inhabit a large number of other material forms such as trees, stones, water-holes and caves. Often they have unusual or abnormal appearances and properties, a uniqueness that sets them apart from normal living things and objects. They can refigure themselves as being monstrous in appearance, taking on the form of an unusual shaped stone, a deformed plant or a two-headed possum, for example.

Their powers of transformation and refiguring allow them to transcend the everyday experiential boundaries to which humans are subject, and this makes them a source of power for humans. The spaces they occupy are important in 
generating knowledge of a magical or aesthetic kind. In the past, these sites were significant in the creation of malangan figures that were displayed at mortuary feasts. More recently, the powerfully charged spaces that larada occupy are the places where men are initiated into the imported shamanic cult of Buai (literally betel-nut or areca nut), which gives them access to the transformative powers that larada embody, facilitating shamanic divination and sorcery flights. Normally the power of transformation over corporeal form is used by larada to trick and invoke fear in people, especially those who transgress rules of avoidance and respect by trespassing upon the larada's abode. This transformative power is termed $i$ axalat, glossed as the power to metamorphose, to trick, challenge, tease and frighten and/or the power to cause harm.

Among the people of the Lelet, clan members do not fear, nor can they be harmed by, the larada of their own clan and the relationship is conceptualized as one of kin. A person can go close to their respective larada and, if it takes the form of a tree or a clump of bamboo, can even cut it down without fear of retribution. ${ }^{7}$ In other circumstances larada are capricious and harmful beings. The dealings between a person who has married a member of a clan and that member's larada is governed by protocols of avoidance and respect. A man or woman must respect the larada of their spouse by avoiding its abodes, which are forbidden places (lenkotkala). The relationship between a person and their spouse's larada is similar to the affinal relations between a mother's brother and sister's son who each call the other's wife nasong and are called nasong by the respective wife. Irrespective of sex, the larada and the spouse occupy the nasong relationship; the spouse must maintain respectful avoidance (lok ngao) of the larada, and vice versa. The relationship of a person to their spouse's larada is one of shame (lok mamang), just like relations between two nasong.

Not only is the relationship between a person and their spouse's larada one of respect, it is also governed by fear, especially when the person lives or visits his or her respective spouse's clan land. This fear leads people to circumscribe their behaviour, and may take many forms, such as not going to certain places at night lest one meet a larada, not washing in a larada water-hole (latbungtada) or abstaining from certain foods. For example, I was told that some people do not eat chickens because, in scavenging for food, they may have eaten a larada in the form of a snake. A person resident on the clan land of his or her spouse does not dispose of rubbish close to places where larada reside lest they consume it, resulting in illness for the careless person. People who live on the land of the larada of their husband or wife try not to disturb the larada in any way. They avoid going to areas where the larada are thought to move, lest they step over its path and subsequently become ill. Choice of a place of residence is often governed by fears for the safety of a spouse. One man told me he did not live near his traditional men's house because it was too close to the abode of a larada 
of his clan and he feared for the safety of his wife who had nearly died previously when she cut a snake larada from a nearby abode while gardening.

People who do not respect and avoid the larada in a nasong relationship are likely to have their body colonized by the larada, causing illness and even death. It is said that the larada, seeing that a person does not exhibit shame, decides to marry that person, a euphemistic way of saying that the larada has sexual intercourse and colonizes the internal spaces of the body. One such account illustrates the transformative power of larada vividly. This involves the larada of Tunau clan, Lubungumo, a black python with two heads (one head coloured with red ochre and the other coloured white with lime powder) who is reputed to have killed several men and women who disregarded affinal etiquette by venturing too close. In one case a woman had sexual intercourse with a man at the abode of Lubungumo, who seeing this transgression, invaded the woman's body as retribution. During the daylight hours the woman's stomach became distended by the snake inside. The larada migrated at night, so that her swollen stomach slackened. Leaving via her anus, the larada snake, "screeching like a pack of rats", would return via the same orifice to recolonize her body at dawn. This continued until her death, whereupon Lubungumo left her corpse and moved back to its usual abode.

This story shows that the effects of not observing the appropriate etiquette of avoidance and shame are catastrophic. Moving into close proximity to a forbidden place inhabited by the larada causes the larada to desire the transgressor - a desire that only ceases at the latter's death.

\section{Seating the Place}

In the earlier discussion of larada, I showed that the body comportment of seating is a trope for the ownership and habitation of place. In the process of larada becoming seated in unclaimed tracts of land, space is possessed, named and converted into an inhabited place for the larada's human kin. In this context seating is an important comportment of the body and is used as a trope for marking the stabilization of identity and its union with space.

However, the evocative ways in which seating is employed go far beyond those I have described in relation to larada. Seating is one of the most widely used body tropes employed on the Lelet, and is commonly used in reference to place and to the social states there. In its most potent usage, it is applied to the community in prosperous and harmonious times - limila.

Limila means much more than the mere abundance of food; it also evokes meanings of social well-being and harmony, a state that is now sometimes glossed by the word "peace". In discussion, people usually say that limila means "the place is sitting down well and there is no disruption" or "the place is seated well and there is an absence of famine". The state of limila is said to exist after war 
or social disruption, times when the village or place is described as "sitting down" well. Similarly, conflicts between people over land, or over various social transgressions such as adultery, are seen to reflect an absence of being seated properly. In a recent sorcery accusation the place was referred to as "sitting down broken" (lixis epeseves) evoking connotations of a community dispersed. People also use similar terms to speak of the loss of traditional ways (loklok at lemenemen, or kastam) and the failure of the younger generation to accept the authority of village leaders. In such contexts, seating becomes part of a moral discourse nostalgically bemoaning the lost power of the leaders and is part of a wider critique of the people's encompassment by colonial and post-colonial social forms in which the past is reified.

The tropic use of the body comportment of seating in relation to food beliefs and famine clearly illustrates the figurative relationship between the body (its states and dispositions) and place. In the cosmology of the Lelet people, the abundance of food comes to symbolize heaviness and immobility whereby the body and place are seated well. The absence of food symbolizes a state of lightness in which both body and place assume a state of restlessness and mobility, and thus neither body nor place are seated well. Famine involves continual movement from settled place to the undomesticated spaces of the forest in search of bush foods that lack the filling and satiating properties of domesticated crops such as taro. In such times, food is not shared among others but is withheld for retention within, and satiation of, the individual's own body, leading to social tensions. Thus, absence of food, and consequently lightness, figuratively represent a state of being characterized by mobility or restlessness with accompanying social tension and disruption. ${ }^{8}$ Heaviness, on the other hand, symbolizes fertility and the abundance of food, accompanied by the values of generosity and general social harmony.

These images of immobility and mobility are exemplified most powerfully in relation to the culturally important root crop taro. Taro is an ambiguous food; on the one hand, it is seen as the archetypal "heavy" food that sits in the stomach giving the body its strength and capacity for productive work (see also Mitchell 1976:25 and Oliver 1971:57). On the other hand, it has the capacity to move away from place, especially through magical enticement or sorcery, thus causing famine. The taro plant is called pas or lavas, and very much signifies movement, these nouns deriving from the two verbs $i$ tpas and $i$ vas meaning to walk. A particular type of magical song is used by people to entice the spirit of the taro's regenerative stalk from other people's gardens to their own. Until recently, the movement of taro from place to place was prevented by the performance of elaborate magical rites, called lemeravas, which were aimed at "seating the taro" (ba xis loxongkun) and thus "seating the place" (ba xis lemenemen). These rituals used powerful magical stones and incantations to make the taro take on the 
heavy and immobile state embodied in the stones, ensuring it was seated firmly in place.

For people to be rooted steadfastly in their place is a highly desirable state. However, it is one that is not entirely achievable since people must submit to the exigencies of life. In certain strategic and pragmatic contexts, mobility is also highly desirable. Seating is only one possibility of bodily comportment and people come to occupy other positions that subvert the trope of seating. Seating is evocative not only of motionlessness and stability; it also implies the potential or intention to move or travel. Thus being seated portrays a transitory position. Being seated, I suggest, is an attitude of the body assumed before or after other states such as sleep, running, walking or standing. A body, for example, is seldom permanently seated, except in the case of infirmity, but sits prior to some form of movement. Mobility subverts the cultural imperative for immobility in place, as these two body images dialectically play themselves out in cultural and social praxis.

Thus, like other tropes and symbols employed by the Lelet people, the conception of seating is not only polyvocal - its meaning varying according to context - it can also be ambiguous. The trope of seating, on the one hand, is associated with abundance and plenitude when taro is firmly seated and famine avoided. On the other hand, it can be associated with characteristics antithetical to this. An example is the immobility occasioned by severe illness and old age leading to death (see also Jackson 1989:148). There is a very poignant song composed by a man made immobile by leprosy. Because of his illness, the man could not host a mortuary feast for a sister and was subjected to the scornful gossip of two other Big Men. The song follows:

I am standing $[a t u]$ here, I am standing, I am standing here, I am standing here. It is only I who remain [nemen] here. I do not have anything for feasting because illness has affected me. Where shall I get good strength from? It does not matter that this illness follows me. You have belittled me, I shall belittle you. They buried the old woman close by. Have you seen the two birds who sit and stare outside here?

It is only I, an orphan, who remains here; my parents are dead and I have chased the two of them before. I am standing here, am standing, I am standing here. It is only I who remain here. I do not have anything for feasting because illness has affected me. Where shall I get good taro and pigs from? It does not matter that this illness follows me. You have belittled me, I shall belittle you. They buried the old woman close by. Have you seen the two birds who sit and stare outside here?

Throughout this song the man reminds the two Big Men that it is only because of his illness that he cannot host the feast for his dead sister. "Where shall I get 
the strength from?" he poignantly asks. He then likens the two men to two birds (luxalanga) who only sit in their hollow-tree nest and stare blankly outside. Commonly, this term is applied to old people who remain in a hunched-over sitting position and are unable to move, occupying what Munn has referred to as "the pole of motionlessness expressed also in sleep, illness, and death" (1986:76). ${ }^{9}$ Although the man refers to the two men in this way, in reality it is he who is rendered immobile, able only to sit and stare out from his house and unable to summon the strength, or to call on support from others, to silence his challengers through feasting. The essential isolation of his plight is emphasized by his constant reference to being an orphan, but despite this the composer allegorically reminds his two taunters that when his parents died he achieved great fame by hosting their mortuary feasts. This is achieved through the allusion to having chased the two Big Men, a euphemistic way of saying that he has humbled them by his feasting efforts. Perhaps the most important point to draw from this song is the constant reference to standing, something I will return to later.

\section{The Mobile Body and Place}

As Tuan has noted, "Place is a pause in movement ... The pause makes it possible for a locality to become a center of felt value" (1977:138). Seating, I argue, can thus be seen as only one state of the many possible comportments and dispositions of the body. The temporary pause in movement embodied in the act of seating allows people to develop an attachment towards that place. Paradoxically, movement is the primary means through which people come to experience, share and know their place, as Merleau-Ponty argues. Movement is the way people inhabit their place, the means by which they mark out the boundaries of the space they own and inhabit. As people move and get to know the space around them better they come to endow it with value (Tuan 1977:6). However, felt and embodied attachment to place does not exist outside of temporality. Over time, as people traverse their place, their experiences of life give further meaning to that place. Not only is the moving body important to the valuing and knowing process but that body occupies a key position in people's understanding of space.

Through the body and its movement, by mere presence of the human being, the world has a schema imposed on it (Tuan 1977:36). As the body moves, its relation to the cardinal directions change (see Codrington 1885:164-165 and Straus 1966:33). Thus, whenever people on the Lelet move from village to village, or from hamlet to hamlet, they constantly reference themselves and their body to space. When people travel, they refer to the direction they are moving toward and/or whether they are moving upward or downward. Objects, too, are positioned according to their orientation to the body. In effect, the body and the landscape it inhabits come to be as one (see Grange 1985:76). 
On the Lelet, walking is the pre-eminent mode of travelling throughout place and is the means by which people come to know and experience the world around them and imbue it with that meaning that socially constitutes it as place. Walking is also a basic precursor to social interaction, one of the means by which social relationships are established and maintained. ${ }^{10}$ People walk from place to place in the process of visiting kin and friends. To remain in one's hamlet and not travel beyond its boundaries evokes the image of the anti-social person, the lantupe, who sits alone in the house not sharing food and eating alone. ${ }^{11}$ There is significance in the fact that the movement between places is negotiated via paths (langas), which allow connection with others in a wider community of sociality and exchange. Paths have important connotations of the way wealth is acquired - by both labour and magical means (see also Bonnemaison 1985:50). Paths are also the sites for the performance of protective magical practices geared to warding off famine and illnesses. In these rites, the magician walks and steps on stones at the hamlet's boundaries, sending any evil influences back along the path from whence they came. ${ }^{12}$

Walking is only one means by which people experience the world around them and imprint their presence on it. Body movement in general can also be said to play this role and is a pre-eminent means through which people define themselves and their position in the world. For the people of the Lelet, one's social self is expanded by the movement of the body, primarily through work in the garden. Through work, manifest strength is strategically realized and transformed into items of exchange at feasts. This process of transforming controlled movement into fame reaches its zenith during the climactic mortuary feast, the lokpanga — where the hosts expand their selves through the distribution of pork and taro. The fact that the giving of exchange items must be reciprocated at later feasts means that the feaster, to quote from Nancy Munn, "can produce for [the self] the possibility of gaining something beyond that time" (1986:11).

The song of the leper, above, is instructive in contrasting the immobility of the sitting birds with the strategic mobility of standing. In the song, standing is a metaphor for hosting a feast, an act which cannot be carried out by the isolated, but only by those who can draw on and muster the support of others. To stand, in this context, is an act of assertion. By repeatedly asserting that he is standing, the immobile leper is showing that he is not yet totally incapacitated. I am not sure whether this assertion is accurate, but as a rhetorical device it is evocative of the man still having power. By asserting that he is standing and his two taunters are sitting, the leper is poetically inverting the actual spatial relationships and hierarchies by positioning his body above their bodies and thus figuratively dominating them. Here he is alluding to the power politics of feasting. At mortuary feasts it is a common practice for the feast host to climb on to a mound of stacked pigs prior to the final pork distribution. The stacking 
of several pigs usually occurs over an enclosure of uncooked taro which will be distributed with the pork after the Big Man has completed his song ( $i$ vavang). In the past, other structures called gilam were constructed. This consisted of uprooting a tree and then inverting it with the top in the ground and the roots above. The structure was reinforced with buttresses and painted red. The receptacle formed on the inside of the roots had taro (or on the coast coconuts) placed there. Pigs are then placed on top of this. At a mortuary feast I attended in the Barok language area in 1991 I saw one of these structures (called kaba among the Barok) erected. About thirty pigs were placed on the top and when the Big Man gave a speech he was about 5 metres above the ground (see also Wagner 1986).

From his position above the gathered crowd of guests, the host sings a song celebrating the efforts of himself and his clan to organize the feast. Often these songs recount the efforts of orphaned children, who, despite adversity, finally complete the mortuary feasting cycle for their parents. At these climactic spectacles the host sometimes brandishes a spear or cordyline plant in an aggressive show of power as he dances on the pigs. This act of dancing on top of the slaughtered pigs is similar to the assertive and aggressive acts of past warriors who danced and sang on the bodies of their slain enemies as they brandished their weapons. In the present post-pacification times, fighting with weapons is to be replaced by "fighting with food" (see M.W. Young 1971).

Bodily movement, such as standing or using one's body in gardening, is valued highly. Failure to manifest strength through gardening work is viewed with extreme disdain, because it is through such directed bodily movement that people create their identity and personhood. The younger generation (mainly young men) are decried for their alleged "passivity" or "laziness" because they do not harness their bodily movement to appropriate ends. Although, paradoxically, they are seen to be in constant movement, these forms of movement are not directed, are unproductive, and hence unvalued. In their travels between hamlets for socializing, young men are seen to dissipate their strength pointlessly, movement which would be better spent, according to their elders, in productive gardening work. ${ }^{13}$ Such uncontrolled movement and travel is referred to as $i$ sasa, a term also used to designate the uncontrolled movement of children as they wander and play, and people who move from hamlet to hamlet around mealtimes in search of food are called lansasa (see also Modjeska 1991:253). This term is also applied to people who move from residence to residence, never becoming settled permanently in one place. This latter form of restless or unrestrained mobility is disparaged. It is an exceedingly cutting insult to refer to a person who moves house frequently in these terms, or as a flying fox, an animal noted for its constant and restless movement. 
Among the people of the Lelet, men's movement is much less restricted than that of women, whose movement in space is hedged with more kinship rules. The spatial positioning of the body reflects the gender hierarchy. Stringent avoidance relations among close kin and affines are practised on the Lelet. Some of the strongest restrictions apply to opposite sex siblings, brother and sister. Thus should a pair of siblings meet on a path, the two should avoid coming into close proximity with each other, the onus being on the woman to move out of the man's path. In practice, this often means a woman turns and moves into nearby bushes, or she may simply look in the opposite direction. If a certain man has carried a flooring beam for a house, women who are in an avoidance relationship with him will not enter that house. If a woman were to step onto a beam that a brother had carried on his shoulder, symbolically she would be surmounting his shoulder. In doing this, the woman has positioned herself spatially above the man, who occupies a place where he can see the woman's genitals. In such contexts, there is a strong equation between seeing and desire. In this spatial positioning, the brother will not be able to control his desire for his sister and the incest prohibition will be breached. Furthermore, this same construction of seeing = desire means that women cannot move spatially upwards by climbing trees because this involves the positioning of their bodies above men.

The gendering of space, body and movement is also apparent in hunting. For example, men are thought to have the strength and speed lacked by women to pursue wild pigs, and so hunting, and the spaces in which it is carried out, are very much a male domain. There is a secret language that is known only by men and used by them to communicate with the various bush spirit beings, lagas (tambaran), that inhabit the forested hunting terrain and control access to game there.

Men are also much more able to move without restriction when they socialize, whereas women must move in pairs to escape the alleged threat of assault. Because of such restrictions and perceptions, women tend to remain located in the domesticated spaces of the hamlet and garden. Women's names, too, reflect the immobile state women embody. The verb to seat, kis, is often used to derive women's names. An example is Kiskot, which means to make one's home in a place which is not a traditional hamlet site. ${ }^{14}$ Men's names tend to be derived from actions or from objects that have connotations of mobility, such as pigs, fish or wealth.

Just as the trope of being seated has ambiguities and is polyvocal, movement too entails ambiguity, contradiction and polyvocality. While movement and travel often involve the expansion of the self as it engages with the world and the people inhabiting that world, it is not unproblematic. According to van den Abbeele's discussion of the metaphor of travel, while movement "posits the risk 
and anxiety of death, it also signals the way to health, wealth, and wisdom" (1992:xvi). Not only does movement from, and within, place pose the danger of loss, but it also poses the possibility of gain. There is potential risk as people move from the places they know and inhabit to other places for exchange, hunting or other pursuits. Moving into the undomesticated spaces of the forest, to hunt or to collect building materials, means to risk becoming lost. This happened to a boy from the village of Lavatkana, who returned to the forest to find something he had lost while collecting building materials, and who himself became lost, never to return.

Another example of the risks involved in movement and travel is the spirit flights practised by magicians schooled in the shamanic arts of Buai. These powers are acquired and transmitted through revelatory dreams which occur at the abodes of larada or lagas. The magical powers obtained from these spirit beings allow the shaman's spirit to travel from his body and enter the corporeal form of another being (eagle, wallaby, pig or shark) to commit acts of sorcery or divination. Although these spirit travels are powerful acts indeed, there is the risk that the spirit of the shaman will not return to his corporeal body, thus occasioning his death. Spirit travels, whether magical or not, can be gainful in producing significant innovations and new forms of knowledge. The acquisition of knowledge and power through dreams and magical flight involves the transgression of the normal spatial boundaries, especially the transcendent vertical spaces which are normally restricted to the movements of birds and flying foxes.

This is the case with the strategic movement used in feasting, which, although it involves the expansion of the self as it engages with the people inhabiting the social world, is not without danger. If a person journeys to a feast, there is the risk of being sorcerized. This can also be the case for feast hosts, who, while

gaining fame from their enterprise, are also left open to sorcery attack by others who are jealous or belittled by the spectacle.

\section{Conclusion}

A primary tenet of this paper is that bodily movement, and the tropes drawn from it, are important in the creation and constitution of place for the people of the Lelet Plateau. The body and its tropes are central to the symbolic processes by which space is realized and possessed as place. It is through these processes that people bestow new imaginative constructions upon space and make it richly meaningful, thus creating their place.

Thus, the Lelet people create their sense of self and personhood through the imaginatively created space which surrounds them. Their sense of who they are and their identity with their place - lemenemen - is creatively constituted through the larada spirit beings who, in their movements, map out the landscape 
as a place of habitation for people. Through the larada, these people have an abiding relationship with the land they inhabit.

A particularly important body trope employed in self construction by the people of the Lelet is that of seating, which has connotations of social harmony and abundance. Nonetheless, there is a recognition of the necessity that other bodily comportments and movements be undertaken in order that people can constitute themselves in their social world. Within this social world, powerful moral discourses censure movement that is not controlled, willed and strategic, and value controlled and strategic movement through which bodily movement can be transformed into fame. Theories of spatiality that posit space as something externally "out there", conceptualized as an object to be acted upon by human subjects, are inadequate because they fail to take into account the complex dialectical interaction between human and space. At the heart of this dualism is "man" as disembodied mind/subject. Some recent anthropological writings on space and place fail in their attempts to overcome the Cartesian dichotomization of space and the human because the body remains absent, in dualistic fashion, in their accounts.

Merleau-Ponty's writings are valuable because, in his critique of Cartesianism, he situates the body and its movement in central place in the theory of spatiality. His theory of lived spatiality is important in breaking down the conceptualization of space as merely an object and seeing it as both constituted by and constitutive of the human subject.

In my elaboration of the pivotal role that the body and its movement plays in the conversion of space into place, my inspiration has been derived from Merleau-Ponty. However, I consider that his theory needs to be supplemented and grounded in a theory of social space and social body. The body whose movement is constitutive of space for Merleau-Ponty is not prior to its symbolic and imaginative constructions and neither is space. There is a strong sense in which space is transformed into place not only through individual experience and perception but through socially derived experience and perception.

\section{References}

Abbeele, Georges van den

1992 Travel as metaphor: from Montaigne to Rousseau. Minneapolis: University of Minnesota Press.

Appudurai, A.

1988 Introduction. Place and voice in anthropological theory. Cultural Anthropology 3(1):16-20.

Basso, K.H. 
1988 "Speaking with names": language and landscape among the Western Apache. Cultural Anthropology 3(1):99-130.

Battaglia, D.

1991 Punishing the yams: leadership and gender ambivalence on Sabarl Island. In M. Godelier and M. Strathern (eds) Big men and great men: personifications of power in Melanesia, pp.83-96. Cambridge: Cambridge University Press.

Bonnemaison, J.

1985 The tree and the canoe: roots and mobility in Vanuatu societies. In M. Chapman (ed.) Mobility and identity in the Island Pacific. Special issue of Pacific Viewpoint 26(1):30-62.

Clay, Brenda

1986 Mandak realities: person and power in central New Ireland. New Brunswick, NJ: Rutgers University Press.

Codrington, Robert Henry

1885 The Melanesian languages. Oxford: Clarendon Press.

Dreyfus, Hubert L.

1991 Being-in-the-world: a commentary on Heidegger's Being and time, division 1. Cambridge, MA: MIT Press.

Entrikin, J. Nicholas

1991 The betweenness of place: towards a geography of modernity. Baltimore: Johns Hopkins University Press.

Feld, Steven

1982 Sound and sentiment: birds, weeping, poetics, and song in kaluli expression. Publications of the American Folklore Society, new series, vol. 5. Philadelphia: University of Pennsylvania Press.

Fernandez, J.W.

1991 Introduction: confluents of inquiry. In J.W. Fernandez (ed.) Beyond metaphor: the theory of tropes in anthropology, pp.1-13. Stanford: Stanford University Press.

Grange, J.

1985 Place, body and situation. In D. Seamon and R. Mugerauer (eds) Dwelling, place and environment: towards a phenomenology of person and world, pp.71-84. Dordrecht: Martinus Nijhoff.

Heidegger, Martin 
1962 Being and time (translated by J. Macquarrie and E. Robinson). Oxford: Basil Blackwell.

Jackson, Michael

1989 Paths toward a clearing: radical empiricism and ethnographic inquiry. Bloomington: Indiana University Press.

Jessep, O.

1980 Land demarcation in New Ireland. Melanesian Law Journal 8(1\&2):112133.

Langer, Monika M.

1989 Merleau-Ponty's phenomenology of perception: a guide and commentary. Basingstoke: Macmillan.

Lawrence, Peter

1964 Road belong cargo: a study of the cargo movement in the southern Madang district New Guinea. Manchester: Manchester University Press.

Leder, Drew

1990 The absent body. Chicago: University of Chicago Press.

Madison, G.B.

1990 The hermeneutics of postmodernity: figures and themes. Bloomington: Indiana University Press.

Merleau-Ponty, M.

1962 Phenomenology of perception (translated by C. Smith). London: Routledge and Kegan Paul.

Mitchell, Donald D.

1976 Land and agriculture in Nagovisi Papua New Guinea (Monograph of the Institute of Applied Social and Economic Research No. 3). Boroko: Institute of Applied Social and Economic Research.

Modjeska, N.

1991 Post-Ipomoean modernism: the Duna example. In M. Godelier and M. Strathern (eds) Big Men and Great Men: personification of power in Melanesia, pp.234-255. Cambridge: Cambridge University Press.

Munn, Nancy D.

1986 The fame of Gawa: a symbolic study of value transformation in a Massim (Papua New Guinea) society. Cambridge: Cambridge University Press.

Myers, Fred R. 
1986 Pintupi country, Pintupi self: sentiment, place, and politics among Western Desert Aborigines. Washington: Smithsonian Institution Press, and Canberra: Australian Institute of Aboriginal Studies.

Ohnuki-Tierney, E.

1991 Embedding and transforming polytrope: the monkey as self in Japanese culture. In J.W. Fernandez (ed.) Beyond metaphor: the theory of tropes in anthropology, pp.159-189. Stanford: Stanford University Press.

Oliver, D.L.

1971 Horticulture and husbandry in a Solomon Island society. In L.L. Langness and J.C. Weschler (eds) Melanesia: readings on a culture area (Chandler Publications in Anthropology and Sociology), pp.52-67. Scranton: Chandler.

Pandolfo, S.

1989 Detours of life: space and bodies in a Moroccan village. American Ethnologist 16(1):3-23.

Pandya, V.

1990 Movement and space: Andamanese cartography. American Ethnologist 17(4):775-797.

Panoff, F.

1970 Food and faeces: a Melanesian rite. Man 5(2):237-252.

Powdermaker, Hortense

1933 Life in Lesu: the study of a Melanesian society in New Ireland. New York: W.W. Norton.

Rodman, M.C.

1992 Empowering place: multilocality and multivocality. American Anthropologist 94(3):639-656.

Stoller, $\mathrm{P}$.

1980 The negotiation of Songhay space: phenomenology in the heart of darkness. American Ethnologist 7(3):419-431.

Straus, Erwin W.M.

1966 Phenomenological psychology: the selected papers of Erwin W. Straus (translated by E. Eng). New York: Basic Books.

Tuan, Yi-Fu

1977 Space and place: the perspective of experience. Minneapolis: University of Minnesota Press. 
Turner, $\mathrm{T}$.

1991 "We are parrots", "Twins are birds": play of tropes as operational structure. In J.W. Fernandez (ed.) Beyond metaphor: the theory of tropes in anthropology, pp.121-158. Stanford: Stanford University Press.

Wagner, Roy

1986 Asiwinarong: ethos, image, and social power among the Usen Barok of New Ireland. Princeton, NJ: Princeton University Press.

Weiner, James F.

1992 The empty place: poetry, space, and being among the Foi of Papua New Guinea. Bloomington: Indiana University Press.

Young, Iris $\mathrm{M}$.

1990a Throwing like a girl: a phenomenology of feminine body comportment, motility, and spatiality. In I.M. Young, Throwing like a girl and other essays in feminist philosophy and social theory, pp.141-159. Bloomington: Indiana University Press.

1990b Pregnant embodiment: subjectivity and alienation. In I.M. Young, Throwing like a girl and other essays in feminist philosophy and social theory, pp.160-174. Bloomington: Indiana University Press.

Young, Michael W.

1971 Fighting with food: leadership, values and social control in a Massim society. Cambridge: Cambridge University Press.

\section{Notes}

1 This paper is based on fifteen months fieldwork among the Lelet people in 1990-91. I have benefited greatly from the constructive comments of Aletta Biersack, Margaret Burns, Jim Fox, Margaret Jolly, Andrew Lattas, Ingrid Slotte, Roe Sybylla and Aileen Toohey.

2 All vernacular terms of the Mandak language are in Palatino italics, while all Neo-Melanesian or Tok Pisin terms are in Helvetica italics.

3 This is not to posit a master trope and I accept the cautionary words of Fernandez (1991:5), Ohnuki-Tierney (1991) and Turner (1991:123). The body and its comportments, I argue, are a significant source of what Ohnuki-Tierney refers to as polytropes (1991:160, 185). She describes polytropes as "polysemic symbols whose multiple meanings in various contexts function as different types of trope" (p. 160). Seating is a very good example of a polytrope being used in a wide variety of domains and contexts, referring to both individual bodily states and collective social states.

4 However, Basso does not take from Heidegger what is equally crucial - the concept of Dasein, or Being as unheimlich (see also Dreyfus 1991:45; Heidegger 1962), the notion that people are never truly at home in the world. The process by which people give meaning and develop attachments to a place is not a process free of tensions, ambiguities and contradictions. This process is not devoid of contestation, either of a symbolic or political nature.

5 The movement of larada (masalai) is not unique to the Lelet. One widely known myth from New Ireland is that of Luanga or Loborada, a giant cannibalistic pig masalai, who in the past terrorized the population, forcing them to flee to nearby islands (see also Powdermaker 1933:34-35 and Wagner 1986:25). A woman was left behind by the fleeing people because she had elephantiasis. The woman slept on a beach and was impregnated by a bird, finally giving birth to twin boys who hunted down the pig and killed it. The death of the pig allowed the people to return to their place. People find the 
authenticity of this tale in various things left behind, such as the stones used to cook the pig at Lesu, or hair which fell from the pig in the Dalom River, forming grass. The mountains of the Lelet Plateau are said to be a result of the giant pig digging the earth. A remarkably similar myth is reported by Battaglia (1991:93-94) for Sabarl Island in the Massim area of Papua New Guinea. In the Sabarl version, the deserted woman steps into a giant clam shell and afterwards gives birth to a daughter. The girl then dresses as a boy and kills the pig. Another version of a cannibal monster forcing the population from their place is to be found on Tanna in Vanuatu (Bonnemaison 1985:36).

6 The realm of the non-human world of the people of the Lelet Plateau contains not only larada or masalai but also various other anthropomorphic and monstrous beings which in Neo-Melanesian are called tambaran and which, locally, are called lagas (singular) or lubungas (plural). As with larada, space and place are also delineated by the paths of movement and the homes of these beings. These bush spirits largely inhabit the forest area, which is called the "big bush" (lavatbuan), although the occasional lagas might live in close proximity to a hamlet, generally in a cave, in a large tree or in a clump of bamboo. Unlike the larada, the relationship between humans and lagas is not one of kinship.

7 This is not the case among another New Ireland people, the Barok speakers studied by Roy Wagner, where the masalai can be wrathful toward, and even harm, the members of its own clan (Wagner 1986:101). A similar situation is reported by Brenda Clay who states that, among the Mandak-speaking people of Pinikindu on the east coast of New Ireland, masalai are feared by clan members and non-members alike for causing illness and even death (Clay 1986:54).

8 The Lelet do not recognize these times as natural disasters but as the wilful action of sorcerers.

9 In the past when people reached old age and became infirm, euthanasia was sometimes carried out.

10 A myth recorded by Panoff from the Maenge of East New Britain (Papua New Guinea) is worth recalling. She mentions a people called the Vagaskusime who remain in the condition of a primeval people lacking a digestive system. In order to eat, these beings throw entire taro or coconuts into holes located on the tops of their heads. Significantly, these people "live seated and cannot move so that they are surrounded by their own excrement" (Panoff 1970:244). This is significant for my interpretation because social interaction, and thus society, is predicated on people being able to move.

11 Literally, people translate this as meaning "man bilong bus", evocative of the tambaran who exists in another realm outside of the web of social relationship founded on acts of giving and receiving food. It also describes the "greedy" person who, in the ultimate act of selfishness, incorporates food that could have been used to initiate and sustain social relationships (Munn 1986).

12 The importance of the path or road has been noted by authors writing on cargo cults - for example Peter Lawrence's book (1964) is entitled Road belong cargo and see Jackson (1989:148) for a different context.

13 Again, paradoxically, one younger informant explained to me that he thought the "laziness" of the younger generation was caused by the increased mobility possible through access to cars.

14 Literally it means to sit down in the middle. Other examples are: Kisalawa, which means to live only a short amount of time; Kisgomat, to live in the place, Lavatgomat; Kismiding, to sit on shell money; Kisbin, to sit down in a place without people; Kisnai, to remain seated; Kisauat, to sit down steadfastly like a stone; Kisina, to sit down on a debt; Kismarua, to sit down in the light; Kiskarun, to sit down without parents. Some examples of men's names are; Marasungaon, a large pig worth ten pieces of shell money; Lumamau, something that has "fight" like chilli; Lavatboorong, good pig; Septupe, to kill something and take it to the forest with you; Bungunen, a school of fish; Ligok, a type of fish; Lavasibo, a bone of a pig; Sorong, to try and spear something; Lentos, to blow on a fire to light it; Lorong, a big or good man. 